\title{
Studies on Governmentality: Six Epistemological Pitfalls
}

\author{
Lika Rodin \\ $\mathrm{PhD}$, Lecturer in Social Psychology, University of Skövde, Sweden \\ Address: Högskolevägen, Box 408, Högskolan i Skövde, Sweden 54128 \\ E-mail: lika.rodin@his.se
}

\begin{abstract}
The notion of governmentality, developed in the works of Michel Foucault, is actively employed across academic disciplines. Reviewing the secondary literature, this paper specifies and systematizes some particularities of Foucault's theoretical account which are reflected in contemporary studies on governmentality. Six latent epistemological obstacles in research on governmentality are described - the essentialization of power; the impossibility of agency and counteraction; latent idealism; the inconsistent presentation of governmentality; the shortage of explanatory perspective on the micro-macro linkage; and a vanishing critical standpoint - to stimulate an academic discussion on possible methodological insights capable of overcoming some of those difficulties. Those limitations are seen to be immanent in Foucault's overall theoretical account rather than the effects of deviation from it. Examples of studies associated with the fields of international relations and sociology support the central arguments of the paper. As demonstrated, the regrounding of a Foucault-inspired analysis of power in the updated version of historical materialism might have the potential to ensure rigor in governmentality research and redefine its critical intent. Further, a consensus is needed on the fundamental notions of governmentality studies to stabilize the research agenda. Recognizing the importance of Foucault's overall contribution to the understanding of contemporary phenomena and practices, scholars need to acknowledge its conceptual and social limitations.
\end{abstract}

Keywords: Foucault, power, resistance, Marxism, biopolitics, idealism, discourse analysis

\section{Introduction}

Two and a half decades have passed since the first publication of Foucault's writings on governmentality in English; we are now witnessing the rise of "governmentality studies," a new cross-disciplinary domain of scientific inquiry (Walters, 2012). Contributions to the research on governmentality come from the fields of economics, organizational studies, political geography, criminology, policy research, organizational studies, research in education and healthcare, social movement and resistance studies, and international affairs (see also ibid.). Governmentality-inspired projects are addressing contemporary social-political phenomena and practices.

Governmentality is defined as a regime of power operating at the intersection of rule and self-management (Foucault, 1997). The term is derived from the notion of "govern-

() Rodin L., 2017

(C) Centre for Fundamental Sociology, 2017

DOI: $10.17323 / 1728-192 X-2017-2-9-28$ 
ment" loosely associated with "the right disposition of things, arranged so as to lead to a convenient end" (La Perriere in Foucault, 1991: 94). It highlights the plurality of power agencies and methods actualized in a nonviolent manner with purposeful but contingent effects (Dean, 2010). Building on Foucault's ideas, governmentality scholars are developing a substantive analytical approach. They increasingly broaden the scope of the research by subjecting to examination previously unacknowledged provinces of power relationships and apply the notion of governmentality to non-Western contexts (Walters, 2012). These attempts require workable research strategies and procedures. Recently, a corresponding body of critical literature has emerged pointing out both the strengths of the governmentality approach (Collier, 2009; Thomas, 2014; Walters, 2012) and certain obstacles to its usage in empirical work (Joseph, 2010a, 2010b; Mckee, 2009; O'Malley, Weir, Shearing, 1997; Rutherford, 2007; Solomon, 2011; Stenson, 2008; Stern, Hellberg, Hansson, 2015). Some commentators associate the difficulties of employing the governmentality concept with deviations from Foucault's theorizing (Collier, 2009; Hamann, 2009; O'Malley, Weir, Shearing, 1997; Rutherford, 2007), while others find those problems to be immanent in it (Barnett et al., 2008; Stern, Hellberg, Hansson, 2015; Thörn et al., 2015).

This paper concerns the epistemology of research on governmentality. Systematizing the critiques of Foucault's theoretical account and the secondary, empirically oriented, literature on governmentality, I identify obstacles that governmentality researchers may face, as streaming from Foucault's conceptual framework. The paper will proceed with a brief outline of fundamental premises of studies on governmentality followed by a discussion on six epistemological pitfalls:

1) the essentialization of power;

2) the impossibility of agency and counteraction;

3) latent idealism;

4) the inconsistent presentation of governmentality;

5) the shortage of explanatory perspective on the micro-macro linkage; and

6) a vanishing critical standpoint.

It further provides a summary demonstrating the need for an academic discussion on methodological insights capable of overcoming some of those difficulties.

\section{Studies on the "art of government"}

Currently, studies on governmentality employ a relatively developed epistemological framework (Walters, 2012). Grounded in Foucault's elaborations, contributions by European and American scholars have sharpened the position on the study object and developed a set of fundamental methodological principles. Dean in a widely cited book Governmentality: Power and Rule in Modern Society (2010) adopts Foucault's mature view on power as noneconomic, decentred, multifaceted, multidirectional, less oppressive, supported by knowledge production and knowledge-effect, power as not just applied to individual subjects but operating through them, and as a complex system of relation- 
ships between control, normalization, and regulation. In addition, two sides in the notion of governmentality are differentiated - government and mentality-to account for the interconnection of material and symbolic, as well as the micro and macro aspects of regulation.

In examining the first element of governmentality-government-special attention is given to heterogeneity, multiplicity, and contingency of power exercise, and power effects. As explained by Dean (2010: 18):

Government is any more or less calculated and rational activity, undertaken by a multiplicity of authorities and agencies, employing a variety of technologies and forms of knowledge, that seeks to shape conduct by working through the desires, aspirations, interests and beliefs of various actors, for definite but shifting ends and with a diverse set of relatively unpredictable consequences, effects and outcomes.

Moreover, Dean suggests examining government in terms of "assemblage" or "regime." The notion of a "regime of practices" or an "organized ways of doing things" (Dean, 2010: 27) becomes prominent in the suggested methodological approach.

As with the classical Foucauldian view, Dean's analysis of governmentality focuses on enactments of power rather than on its ontology. This strategy is able to address borderline manifestations of power: "where its exercise becomes less and less juridical" (Foucault, 2003: 28). Consequently, interest in the techne of power is central in the "analytics of government" (Dean, 2010). Tools, methods, courses of action, and terminology are recognized as forming a relatively autonomous domain, and are subjected to examination with a diagnostic rather than descriptive intent.

Government is characterized by systematicity. Its manifestations are programs aimed at various improvements. Thus, government appears as a fundamentally "Utopian" activity essentially concerned with expedient transformations toward certain ends (ibid.: 44). The related issue of axiology is resolved in favour of the principle of eventuality: "Values, knowledge, technologies, are all part of the mix of regimes of practices but none alone acts as a guarantor of ultimate meaning" (ibid.: 46). This understanding leads governmentality studies to dissociate themselves from a direct emancipatory ethos. Though, as a form of criticism, governmentality studies are hoped to increase individual reflexivity toward the effects of power, including those shaping the practices of self-fashioning.

The second element of governmentality-mentalities of government-is associated with the rationalities which provide an epistemic and moral environment for practices, being simulations irreducible to them (Dean, 2010). Authorized knowledge claims are not the only source of governmental rationalities. Paradoxically, similar to the collective consciousness, mentalities of government are said to carry elements of social-political imagery that might be unrecognized by social actors (ibid.: 25; see also Rodin, 2015). "Mentalities of rule" are central to understanding the mechanisms of subjection and the complex relationships between the exercise of power and individual experiences, as well as self-management. Acknowledging the absence of the immediate shaping of identities 
by power, governmentality studies zoom in to the indirect facilitation of individuals in assuming themselves as subjects. The affirmation of freedom embedded in the notion of government as the "conduct of conduct" is central in sustaining the effects of the rationalities of rule (Dean, 2010: 24).

These fundamental premises artfully summarized by Dean (2010) have been informing the empirical research on governmentality through the last decade with distinctive outcomes. As the initial fascination with Foucault's approach started to calm down, critical writings emerged addressing the applicability of the governmentality framework in empirical research. Currently, the main body of critique comes from the scholarship associated with studies on international relationships and sociology. While the former seems to be more concerned with macro level manifestations of governmentality, the latter focuses on the micro level of governing and practices of self-management. I will employ examples from the two academic fields that accommodate studies on governmentality to exemplify the claimed limitations of governmentality approach as part of the Foucauldian tradition itself.

\title{
Epistemological pitfalls
}

In this section, I outline six hidden obstacles that governmentality researchers may face: the essentialization of power; the impossibility of agency and counteraction; latent idealism; the inconsistent presentation of governmentality; the shortage of explanatory perspective on the micro-macro linkage; and a vanishing critical standpoint.

\section{The essentialization of power}

The conceptualization of power in Foucault's writings is frequently associated with an effort to overcome the issue of economic determinism in orthodox Marxism (Barrett, 1991). According to some commentators, this resulted in the degrounding of power and its essentialization (Poulantzas, 1978; Resch, 1992). As specified by Resch (1992: 251):

\begin{abstract}
Power precedes structure and therefore cannot be deduced from it. Power is thus some kind of undifferentiated force or energy that circulates through social formations and is basic to them. It is ultimately unimportant (as well as impossible) to distinguish ideological, political, economic, or theoretical practice, for such distinctions don't really matter: they are all merely forms of power. It is never, with Foucault, a question of what power and for what purpose, since power is always already there, obeying its own laws, and its only purpose is its own expansion.
\end{abstract}

As argued, Foucault built on the explanation of "society in terms of power," rather than "power in terms of society" (ibid.: 249). This "totalizing" view restricted his analysis of the relationships between distinctive power forms (e.g., between biopower and economic domination) and an explanation of resistance mechanisms. Eventually, the overall 
theoretical promise to account for the "real' complexity" of social-political life was left unfulfilled due to an unsophisticated power ontology (ibid.: 250-251).

Barrett (1991: 152) adds on the issue of "false universalising" in Foucault's approach, warning against a reduced analytical sensitivity to the relationships between different power forms. The universalising approach can moreover result in Eurocentrism. Building theory on the history of Western civilization, Foucault latently "reterritorized" power (Solomon, 2011) and left aside, it is argued, the colonial aspects of rule and subjugation (Barrett, 1991; Joseph, 2010a; Walters, 2012). As Said famously noted:

$[\mathrm{H}] \mathrm{e}$ does not seem interested in the fact that history is not a homogeneous French speaking territory. ... He seems unaware of the extent to which the ideas of discourse and discipline are assertively European and how ... discipline was always used to administer, study and reconstruct-then subsequently to occupy, rule and exploit-almost the whole of the non-European world. (Said in Barrett, 1991: 152)

Eurocentrism is frequently found in the empirical analysis of the art of government (Joseph, 2010a; Rutherford, 2007; Walters, 2012). In the field of international relationships, it manifests in the "scaling up" problem associated with a direct ascription of Western notions to non-Western phenomena (Walters, 2012; see also Joseph, 2010a). The governmentality approach appears blind to differences between countries and to the classical issue of "combined and uneven development" (Joseph, 2010a). To overcome this difficulty, Joseph (2010a, 2010b) suggests focusing on the actual asymmetries in the economic and social-political conditions of different societies, and on the ways in which Western institutions promote neoliberalism in different parts of the globe. The question then emerges of whether, or to what extent, "governmentality" can be helpful in understanding non-Western semi-liberal power orders.

Collier (2009) misrecognizes the totalizing tendency in the overrepresentation of "power/knowledge" logic_an idealistic element of Foucauldian theorizing (Rehmann, 2013) discussed below-in contemporary examinations of governmentality. Power/ knowledge is said to undermine the view of social-political relationships as contingent and unfixed, and therefore limiting the explanatory potential of governmentality research. Collier's alternative suggestion is to resort to a "topological" analysis, which can uncover "a heterogeneous space, constituted through multiple determinations" (Collier, 2009: 99). He tests this approach in a study on power regime in Russia. Other scholars advocate for ontology "in becoming." Walters (2012: 57) highlights a less (pre)determined "historical ontology" and "the regime of truth, the practices and strategies that ontologize the world in the first place." Barnett et al. (2008: 9) calls for assuming rationalities not as given, but arising out of social interactions, to account for the "communicatively mediated, normatively oriented interaction through which such emergent cooperative rationalities can develop." In the analysis of the consumer narrative on ethical consumption, Barnett and colleagues argued that dominant consumer-oriented rationalities do not necessarily turn individuals into subjects of neoliberal power. Identity appears as 
a more complex and contradictory entity, embodied in the social reality and produced through nearly symmetrical interactions with others and social institutions.

However, dissatisfaction with the essentialistic definition of power, the "flat" or unspecified ontology continues to grow. Critical commentators, as mentioned above, point out the shortage of its explanatory potential without reference to local and global structures (Hartsock, 1989; Joseph, 2010a, 2010b). In regard to the Russian case examined by Collier (2011), the failure of budgetary and heating system reforms in a middle-size city in South Russia in the 1990 os might be less puzzling. According to him, the reforms were inspired and facilitated by transnational agencies, which determined their neoliberal character. However, the centralized hardware developed in Soviet times, the related ideology, and habitus prevented the intervention being effective. Following Foucault's tradition, Collier looked for an explanation in the modalities of neoliberalism and its relationships with sovereignty and biopower. An alternative to such a topological view is the recognition of the remaining material and discursive regularities. In this way, the construction of the heating system embodied the socialist principle of collective consumption, which restricted the individualization of the heating provision. The collective principle was furthermore supported by the remaining elements of the official ideology of social justice and related institutional routines. Jointly, these features limited deregulation attempts. Joseph (2010a) adds an international perspective on the governmentalization of developing societies. In the context of insufficient national authority, the import of governmental technologies, as those presented in the Russian case, should be viewed as a specific type of "imperialism," signalling a structural operation on a global level (ibid.: 238).

The flexibility and fragmentation of power-one of Foucault's central claims adopted by governmentality studies (Dean, 2010) - is yet another important element in the discussion on essentialization. Power diversity is frequently associated with the "decentring" of the state and an emphasis on an "apparatus" and/or "dispositive." The apparatus and/ or dispositive is a "heterogeneous ensemble" and a "system of relations" between diverse material and symbolic aspects of social reality, and a "formation" serving the "dominant strategic function" (Foucault, 1980: 194-195). Contemporary research on the art of government frequently finds apparatus/dispositive to be a useful conceptual and methodological tool. Rehmann (2013: 207), being overly critical toward Foucault's framework, emphasizes an empirical validity of the concept of dispositive interpreted as the "arrangement of an apparatus" and in terms of "an institutionally fixed spatial-temporal composition which subjugates the subject to the technologies of power," including, for example, the architectural arrangements of a prison system. This interpretation dissociates from Foucault's rather Nietzschean view on apparatus/dispositive (Foucault, 1980) focusing on its material dimension.

Some scholars, however, are more sceptical to the concept of apparatus/dispositive. First, the concept is criticized for the puzzling claims of systematicity and the programmatic nature in the absence of any specific point of power concentration. Barrett (1991) suggests that "strategies" and "technologies" appeared in Foucault's writings as both deliberate and lacking a specific subject employing the force (see also Foucault, 1980). 
Moreover, "effect" - an outcome of power application-was hard to imagine in the context of Foucault's overall disregard of the very idea of causality. Second, relations of force presuppose struggle, but "who is doing the struggle and against whom" (Miller in Foucault, 1980: 207) in the context of absent structures? Responding to this question, Foucault (1980: 208) resorted to abstract inter- and intra-subjective contradictions: "There are not immediately given subjects of the struggle, one the proletariat the other the bourgeoisie. Who fights against whom? We all fight each other. And there is always within each of us something that fights something else."

As we will see later, the discussion on power ontology fundamentally informs other aspects of Foucault's theorizing on governmentality and, eventually, governmentality research. When ontology is not acknowledged or is refused to be acknowledged, it does not necessary imply that it is "in becoming," but rather that it is unreflected by the researcher him/herself. This may lead to a shortage of explanatory propositions in the analysis of social-political phenomena and processes, and a focus primarily on an "objective" description of power mechanisms undermining the diagnostic intent of the "analytics of government" (Dean, 2010). A clear ontological position would moreover allow the limitations of the governmentality framework, contexts, and situations where its relevance is problematic to be seen (Joseph, 2010a).

\section{The impossibility of agency and counteraction}

The issue of individual self-directedness and social antagonism is highlighted in regard to the concept of power underlying the analysis of governmental rule. The first concern is with the very possibility of agency and resistance. Poulantzas (1978) problematizes Foucault's famous claim of the "relationality" of power, pointing out its all-inclusive nature. "For if power is always already there, if every power situation is immanent, why should there ever be resistance? From where would resistance come, and how would it be possible?" (ibid.: 149, original emphasis). If we assume power as "relations of force" and explain the related struggle, where would this struggle be grounded in? For Poulantzas, resistance, when collapsed with power itself, appears rather as a declaration. As he explained further with a reference to Marxism, "If struggle has primacy over apparatuses, this is because power is a relation between struggles and practices (those of the exploiters and the exploited, the rulers and the ruled) and because the State above all is the condensation of a relationship of forces defined precisely by struggle" (ibid.: 151). Discussing other paradoxes of Foucault's argumentation, Palmer (2001: 335) provocatively applies the notion of power relations- "instances of actions of one party changing the behaviour of another party" necessarily presupposing a type of "resistance" or counteraction-to human-animal interactions. Could it be argued, he askes, that a situation in which a man attacks a cat and the cat actively defends itself presents power relations, while another context in which the man beats a tied up cat is simply violence, because the animal does not/cannot respond? According to this logic, sovereignty, for example, cannot be accepted as a "proper" power form. 
"Since power is everywhere, everything is contestable" (Resch, 1992: 253). Following this Foucault's proposition, researchers keep looking for resistance in all contexts where power is exercised, and they can be puzzled when they do not find clear evidence of it. The Swedish sociologist and social movement researcher Håkan Thörn presented this type of situation in one of his interviews. Examining the experiences and responses of civil society organizations involved in international AIDS aid programs in Africa, the scholar had to imbue the words of the study participants with "latent" meanings. More specifically, an expression recorded during a focus group with NGO leaders: "We want ... to be able to stand up and write a good proposal" was interpreted as a "critique of the depoliticizing effects of contemporary international aid," while it could perfectly well mean (as a colleague of Thörn also pointed out) just a subscription of civil society activists to the discourses of Western benefactors (Thörn et al., 2015: 97). Thörn, however, refuses a "reductionist" view of the situation as a simple ideological interpellation looking for manifestations of agency. The question, however, remains, if this approach risks becoming a new reductionism by excluding other explanations.

Gradually, the notion of a "submerged critique"-latent resistance elements in nonresistance-became the unit of analysis. It organizes a "space of agency" signalling the possibility of a deliberate choice (ibid.: 98). In this context, individaul suvereignty appears to be reactive and the overall perspective of an emancipatory project driven by a "transformative agency" remains rather unclear. Moreover, the detection of such hidden resistance would demand "an external standpoint" (ibid.: 100), which is difficult to imagine within the Foucauldian understanding of power as an essence of the social. Not surprisingly, Thörn eventually proposes a return to a post-Marxist perspective on power as a "capacity" shaped by an agent's contextualized positioning within the system of social regularities and institutions.

If freedom is a derivative of power, its "technical modality" (Dean in Joseph, 2010a: 228), how can we make sense of it in an empirical study? When analysing the manifestations of agency, how can we methodologically differentiate self-directedness from domination (Stern, Hellberg, Hansson, 2015)? One solution is to code social practices for markers of deviation from the imposed script. Thus, Thörn in his study on international AIDS aid in Africa identifies two examples of NGO agency. In one case, a civil society organization submitted to the funding body a critical note instead of reporting on the utilization of financial aid. In another case, NGOs formally agreed on a certain condition imposed by donors but sabotaged it in practice (Thörn et al., 2015). If such reactive acts are empirically observable and accessible to validation, the analysis of submerged critique based on an examination of discourse would be fully left to the subjective interpretation of a researcher. The externality of the interviewer to the dominant discourse would be difficult to ensure in each case, while interpretation would need to be grounded in some recognizable alternative narrative. Critical discourse analysis resolved the issue of rigor by subscribing to a combination of historical materialism and discourse theory (Jørgensen, Phillips, 2002). For governmentality studies, this problem will be more complicated due to the essentialistic noneconomic all-inclusive notion of power, the primary 
focus on techne, and, as Foucault was charged himself, silence on a researcher's own ideological positioning (Barrett, 1991; Resch, 1992).

Special attention should be given to a rationalistic imperative that appears to shape the methodology of governmentality research. Irrational elements of mentality (Dean, 2010) that could account, for example, for ideological effects or habitus are mainly absent. Lemke (2013) furthermore challenged Foucault's definition of power as being built on a nonspecific notion of rationalities. Affective aspects, such as fear, are important in the recruitment of individual actors to political action: "By adhering to a rather abstract concept of rationality, studies of governmentality have tended to neglect the political significance of expressive and emotional factors in favour of conscious calculations and elaborated concepts" (Garland in ibid.: 40). It seems that studies employing ideas of governmentality frequently follow the "rational choice" approach in examining practices of (non)resistance: "because it involves the possibility that the absence of resistance might be the result of strategic considerations (resistance is too costly, fruitless, etc.)" (Thörn et al., 2015: 98). Barrett (1991) criticizes the rationalization of an individual as echoing the conventional discourse of economics. Moreover, with the exclusion of emotions, social movement studies lose a plausible explanation of resistance. The question of counteraction thus remains open in the Foucauldian orthodox tradition. Foucault's ethics are sensitive to a certain pull of emotions, but there is no longer power around to resist (Resch, 1992).

\section{Latent idealism}

Foucault is frequently found keeping up with post-structuralism in his analysis of governmentality (Resch, 1992; Thörn et al., 2015). Resch (1992) suggests that, proceeding from archaeology to genealogy, Foucault reframed his theory of discourse with regard to a newly invented concept of power. Knowledge became dissociated from any material reality and turned into power effects constituting social identities and practices. Studies on governmentality inherited the idealistic aspiration (Barnett et al., 2008; Mckee, 2009; O'Malley, Weir, Shearing, 1997; Rutherford, 2007).

Addressing this trend, Rutherford (2007) asserts that research on governmentality tends to focus on the interventionist rhetoric produced by different social and institutional actors. This approach was said to ignore the empirical aspects of implementation and thus was dissociated from the opportunity to account for possible contradictions, resistances, mishmashes, and other "messy empirical actualities" (Mckee, 2009: 12, see also O'Malley, Weir, Shearing, 1997). Barnett et al. (2008) add that emphasis on the intentionality of government-its strategies and objectives of rule-imbues it with a functionalist framework and overly risks subsuming analysis under theorizing. It, moreover, leads governmentality studies toward epistemology and the methodology of discourse analysis with all the typical limitations, including a sampling quest: "which texts are to be adjudged definitive of a political rationality or programme" (O’Malley, Weir, Shearing, 1997: 514). 
To resolve the problem of dematerialization, some scholars advocate the accumulation of more relevant and richer empirical data obtained by means of, for example, ethnographic methods. Such a "realist governmentality" approach (Stenson in Mckee, 2009: 18) is believed to be capable of detecting and describing the incoherence and complexity of social practices (Mckee, 2009). This strategy, however, can be of limited value without sufficient explanation of the relationships between the material and the symbolic. In Foucault's early writings on discipline, discourses were seen as informing the materiality of institutions, techniques, and practices (Foucault, 1995). This linkage was weakened in his post-structuralist period when discourse reappeared as a power itself "which is to be seized" (Foucault, 1981: 53). Not surprisingly, when attending to materiality, governmentality scholars continue treating it as being separated from (dominant) rhetoric and occasionally as a source of its contestation. Thomas (2014) studied the implementation of the Unique Identification program in India and attempted to explain its failure: the program was of limited use due to its inability to address for individuals whose bodies are not "readable" by contemporary technological devices. The scholar acknowledged the fact that those devices seem to be constructed with some specific idea of an identifying subject-an urban well of non-manual workers detached from hazards of heavy, low-protected physical labour that dramatically affects body properties such as finger prints-but still interpreted the technical fiasco of the program as a contingent effect and a "variance between intended rationalities and concrete technologies of governance" (ibid.: 177). The interpretation of relationality in terms of tensions between the discursive and non-discursive leads some governmentality scholars to link contestation with imperfections of the subjects or the technologies which eventually undermined implementation of the program (see Miller, Rose, 1990).

\section{The inconsistent presentation of governmentality}

As argued, Foucault's account does not present a complete social theory, although studies in governmentality frequently treat it as if it did (Lemke, 2013). The focus of attention shifted dramatically in Foucault's theorizing from a more structural approach, under the influence of Althusser, to post-structuralism and then to a peculiar combination of both (Resch, 1992). During the period of 1976-1979 alone, when the concept of governmentality emerged and obtained its shape, the focal point of Foucault's research, vocabulary, and method changed notably (Collier, 2009). Biopolitics, introduced in The History of Sexuality 1 (1976) as a power over life radically differentiated from both sovereignty and discipline, was developed in the series Society Must Be Defeated (1975-1976). Here, biopower reappeared under a new name "regulatory power" and was complemented by disciplinary technologies to comprise "normalization." In the next lecture series Security, Territory, Population (1977-1978) "regulatory power" turned into "security" with a new move to dissociate it from discipline. Along with this transformative process, the role and ontology of both power and population evolved. Primarily understood as all-embracing and controlling, the power of the state was gradually reduced and decentred, giving way 
to a plurality of power agents; the image of a passive and mainly homogeneous population was redefined in terms of a "principle of limitation' on state activities" (Foucault in Collier, 2009: 87). These moves demonstrated Foucault's abandonment of the linear progressive logic of power development (the correspondence of each form of power with a specific historical period) and his refocus on the composition and interactive articulation of different power forms (ibid.). Foucault's attention was then occupied by the phenomenon of (neo)liberalism as a form of governmentality in the series of lectures The Birth of Biopolitics (1978-1979). Finally, during the early 1980s, his writing became concerned with yet another new theme-the technologies of the self-for which power re-emerges as a "social background" (Resch, 1992: 254). Rehmann (2013: 306-307) differentiates four meanings of governmentality found in Foucault's writings - "the particular conception of political leadership," "political governmentality"/“raison d'Etat," and "the liberal art of government"- wondering about any possibility of a shared foundation for governmentality studies. Some scholars go further, suggesting that the affinity of research presented under the umbrella of governmentality studies is grounded generally in "reference to Foucault" (Wallenstein, 2013: 8).

Given the perception of Foucault's account as incoherent and at times contradictory, the wide diversity of interpretations of the main concepts among governmentality scholars is understandable. This feature, however, might limit the acceptance of the analytics of government as a substantive research field. Four tracks can be differentiated in the research utilizing Foucault's ideas from the late 1970 s to the early 1980s: government as a discipline, government as biopolitics, neoliberalism as governmentality, and governmental self-management. To exemplify the various interpretations and the related research directions, an anthology Prevent and Tame: Protest Under (Self)control edited by Froian Hessdöter, Andrea Pubs, and Peter Ullrich (2010) looks at the condition of (neo)liberal society through the lens of discipline. "Preventism" is defined by one of the editors as a technology of government, a "panopticon without a centre, an omnipresent panopticon 'embodied' in the individuals' minds as well as in discourses and social practices" (Ullrich, 2010: 20). Another anthology, Transformations of the Swedish Welfare State: From Social Engineering to Governance (2012) edited by Bengt Larsson, Martin Letell, and Håkan Thörn, builds on the notion of "governing from a distance." It finds a legacy of neoliberal governmentality in modern programs of social engineering (biopolitics) but goes beyond it. The book's contributors examine the contexts and practices of social-political steering, and regulation in the spheres of healthcare, urban planning, labor market, and other areas with special attention paid to the role and (dis)positioning of the state. A special edition of the international journal Ephemera "Governing Work through Self-Management" (2011) examines the diverse practices of self-management in work life. Finally, Read (2009) explores governmentality as neoliberalism and the related process of the formation of the self. Barnett et al. (2008) add to the discussion of the production of subjectivity on the analysis of consumer attitudes in relation to ethical consumption. The authors are interested in the phenomenon of "subjectivization" and the role of norms in shaping consumer subjectivities. Power is rather loosely presented in this discussion; 
instead, the major concern is with horizontal interactive processes occasionally competing with vertical ideological effects.

Taking into account the variability of interpretations, Solomon (2011) defines governmentality as an element of the wider phenomenon of biopolitics. Similarly, Joseph (2010a) views biopolitics as an inclusive term, while associating governmentality with the interplay between liberty and discipline. The combination of those is sometimes accommodated under the name biopolitics. The idea of "global governmentality" is rejected as lacking empirical evidence. In contrast, Wallenstein (2013) interprets governmentality as a synonym of government applicable to a variety of historical contexts. He links the widely assumed association of governmentality with (neo)liberalism to the order of the release of Foucault's lectures for the academic public. Other scholars are less concerned with a need for precise terms (e.g., Rutherford, 2007).

Several proposals emerged to resolve the confusion in Foucault's terminology. Joseph (2010a: 227) suggests a differentiation between governmentality in a "generic sense" and "special (neoliberal) governmentalities." The first was initially concerned with population management and gradually started to obtain neoliberal characteristics; the later ones deal more with liberty as a mechanism of governance. Joseph warns analysts of international relationships about mixing together all the power modes (including sovereignty and discipline) without an understanding of how each of them contributes to a specific power regime. Lemke (2002) advocated a more radical reading of Foucault with the help of a continuum of power stretching between "a strategic game" and "domination" with government situated in between those two poles occasionally leaning toward one or the other: "technologies of government account for the systematization, stabilization and regulation of power relationships that may lead to a state of domination" (ibid.: 53).

If government as a strategic rule is a part of the milieu composed, among others, by more oppressive power forms, how can one analyse resistance? Lilja and Vinthagen (2014) made an outstanding attempt to map the various forms of resistance associated with distinctive power forms. The question, however, arises: to what extent can these strategies and practices specifically targeting sovereignty, discipline, and biopower be studies in the context of the complex interweaving and interrelated articulation of different power modalities? As Lemke (2013: 40) specified: "Especially since 9/11, the intimate relationship between governmentality and sovereignty, between neoliberalism and discipline, freedom and violence, can no longer be ignored." Foucault's resolution of the issue was the removal of power from the picture of the neoliberal order along with the very idea of resistance, and the move toward what Resch (1992: 254) termed "neo-liberal humanism."

\section{The shortage of explanatory perspective on the micro-macro linkage}

The issue of the interconnection between distinctive levels of sociality-structural and individual-has always been a central concern in social sciences (Ritzer, 2008). Foucault's diverse projects claimed to provide insights into the operation of power at both 
the micro and macro levels, in association with discipline and biopolitics, respectively. Moreover, his late elaborations attempted simultaneously to address the power dynamic and subjectivity in the concept of governmentality. Despite such an all-encompassing claim, empirical studies on the art of government may find Foucault's framework neither micro enough, with a need to add concepts and methodologies of actor network analysis (Edwards, Nicoll, 2004) or ethnography (Mckee, 2009), nor sufficiently macro (Joseph, 2010a). Furthermore, certain confusion can be found in Foucault's overall discussion on the mechanism of consent which would explain the macro-micro linkage. As Foucault (1990: 38) put it, a mechanism of "how the reflexivity of the subject and the discourse of truth are linked."

In the conceptualization of government, Foucault turned away from the disciplinary mode of consent constituted via insocialization of certain courses of thought and action by individuals being subjected to hierarchical observation and examination (Foucault, 1995). Instead, emphasis was put on techniques of self-examination and self-disclosure; confession replaced training. Confession is described as a technology of power to construct the subject by means of 1) self-exposure that enables control and 2) the framing of the subject's own cognitive and psychological states in line with the discourses of power (Foucault, 1997; see also Fejes, Dahlstedt, 2013; Rodin, 2016). The metaphor of a moneychanger who verifies and weighs coins to confirm their value is used to explain the "Christian hermeneutics of the self"; one has to monitor continuously his/her own thoughts in regard to one's duties to God. Eventually, the liberating potential of "technologies of the self" appeared to be mediated by technologies of domination.

With the vanishing of power from Foucault's later writings, concern with subject (and consent) was replaced by attention to subjectivity (and self-management). Barrett (1991: 91-92) explains the difference between the notions of "individual," "subject" and "subjectivity" in contemporary theoretical practice. The term "individual" highlights "personal existence" as distinct from a more traditional "functionalistic" view of a person. It may signify one's presocial state, the meaning assigned to Althusser's interpellation process, though this connotation is frequently seen to be problematic. "Subject" signifies "the model of cognitive security and confident agent"; it is discussed in relation to the notion of an object and related effects of subjection. "Subjectivity" comprises both reflective and unreflective elements, and cognitive and emotional aspects to describe the "private sense that individuals make of their experience and how this varies from content to context" (ibid.). In Foucault's early texts, we find an individual subject; confession deals with the interplay between subject and subjectivity, as earlier an Althusserian interpellation, based on a feeling of guilt (Butler, 1995). With the disappearance of power in Foucault's later writings the "hermeneutics of the self" focused entirely on subjectivity, feelings of pleasure and the aesthetization of life. This move resonated with the expanding discourse of individualism and personal welfare (Barrett, 1991). It can be argued that Foucault earned his popularity among an academic audience not only by the detailed description of the micromechanics of power but by his attention to the phenomenon of subjectivity, requested by the new social movements and related research (ibid., see also Newton, 1998). 
However, the understanding of consent, a crucial element of a liberal order (Poulantzas, 1978), has become problematic. Focus has shifted toward the issue of relations with the self, echoing Giddens' (1991) elaborations on identity as a reflexive project.

Currently, the notion of "subjectivization" is becoming salient in research on the art of government. As explained by Barnett et al. (2008), it reimagines an individual social actor as constituted via social interactions. The notion of "lay normativity" mediating grand ideologies is used to explain variations in framing conduct among ethical consumers. It remains, however, unclear where this normativity can be grounded in and what exactly the relationships between macro- and micro-norms, meaning, action, and identity (see the related discussion on the Habermasian approach in Haferkamp, 1985). Can it just be assumed that lay normativity brings "noise" into the process of ideological interpellation without radically undermining its preprogrammed effects? An acknowledgment of the cognitive and interactive aspects of social life is helpful in increasing the possibilities of individual self-directedness. However, self-reflexivity or "the narrative construction of the self" that is said to mediate subjection and subjectivization can hardly be taken as prehistorical/preideological. As is known, micro-sociological traditions such as symbolic interactionism finally resolved the issue of the micro-macro linkage by recognizing the complexity of the structural/institutional organization of society and introducing a structural view of identity (Stryker, 1982). Within the Marxist tradition, Therborn (1982) corrected Althusser's functionalist and totalizing view of ideology by acknowledging the interaction (and at times competition) between a multiplicity of structurally grounded ideologies which contribute to the complexity of individual identities and forms of subjection. This move might be especially important in the understanding of how collective (counter)identities and (counter)actions are possible. The promise made by the analytics of government to account for the complexity of relationships between power and liberty frequently remains unfulfilled due to a shortage of explanatory resources in Foucault's theoretical doctrine. In practice, one part of the dyad becomes muted in empirical studies, producing a one-dimensional picture of social-political phenomena and processes.

\section{Vanishing critical standpoint}

One of the most persistent criticisms of Foucault's theorizing is the absence of a discussion on his own position in relation to political power (Barrett, 1991). Despite Foucault's early concern with exposing oppressive apparatus of power and his personal engagement in the social activism of the 196os, elaborations of Foucault's own ideas are found overtly facilitating the existing power order (Behrent, 2010, see also Hartsock, 1989; Polauntzas, 1978; Rehmann, 2013; Resch 1992; Stern, Hellberg, Hansson, 2015). A disregard of Marxism and socialist aspirations, the discredit of the state (Behrent, 2010), and the support of individualization (Resch, 1992) are seen as contributing to the neoliberal agenda. As Resch (1992: 255) put it referring to Foucault's American period: 
Foucault's new attention to the subject, coupled with his fragmentation of social structures into autonomous spheres, does provide a coherent defense of neo-liberal micro-politics, but it offers no analysis of the complexity of political problems or the obstacles standing in the way of their resolution. . . . Foucault's new methodology signifies nothing more than the capitulation of postmodern dissidence to the liberal capitalist status quo.

Behrent (2010) highlights the rise of "Right Foucauldianism," a phenomenon exemplified by the case of Foucault's former assistant and editor of his publications, François Ewald, who abandoned academia and became a successful businessman. Foucault's ideas, Ewald argued, helped on this way by liberating him from revolutionary theory and vocabulary. While Foucault's constant return to the issue of resistance created an aura of radicalism, it undermined his critical agenda, redirecting attention away from the analysis of class oppression and the related struggle (Resch, 1992). Not surprisingly, governmentality scholars reject the very idea of transformative political action, because "[t]he imposition of yet another programme of rule might only add to the array of possible oppressions" (O'Malley, Weir, Shearing, 1997: 504), a move which would lead away from the initial concern of governmentality studies with "opportunities for difference and contestation" (ibid.). To imagine those deviations and contestations, a robust conceptual foundation explaining the possibility of counterstructures of counternarratives would be needed. Otherwise, the notion of struggle frequently employed by governmentality literature will remain a Marxist ghost rather than a workable concept. Critique as a stimulator of reflexivity (Dean, 2010) may eventually be substituted by diagnostics for their own sake (O'Malley, Weir, Shearing, 1997) or even benefit power becoming an essential element of (neo)liberalism itself (Rehmann, 2013). As Rehmann (2013: 309) specified, Foucault's theorizing "uncritically identifies with the object and remains on the level of an intuitive and empathetic retelling."

Thus, the analytics of government inherited the trend of depoliticization and "liberal bias" (Walters, 2012: 50). Hamann (2009) observes that focusing research agendas on the practices of self-fashioning might be seen as echoing the discourses promoted by neoliberal governmentality. In regard to studies on international affairs, Joseph (2010a) warns that an uncritical application of the notion of governmentality may facilitate the promotion of views on global order as a neoliberal one. Walters (2012), with reference to Lemke, finds resemblances between the governmentality approach and liberal theory of governance. Moreover, the image of "productive" power that had championed in Foucault's writings the idea of oppressive and coercive rule risks narrowing the research agenda (Hamann, 2009).

\section{Discussion and Conclusion}

The concept of governmentality has enlivened a variety of academic fields with a growing amount of research addressing the art of government in distinctive spheres of social- 
political life. Some scholars, however, still doubt that it is effective to talk about governmentality studies as a substantial branch of scientific inquiry considering the absence of a coherent theory of governmentality in Foucault's account. As Wallenstein (2013: 10) proposed: "If there is a unity, it must rather be sought on the level of questioning, in the necessity of never remaining satisfied with the answer just given, and of constantly returning to the starting point in order to frame the investigation differently." As demonstrated in the current paper, the shortage of explanation on power ontology and the continuous transformation of the focus of Foucault's research provided unstable ground for the conceptualization of both power and agency and the relationships between them. In this context, Foucault's account is frequently considered as a "toolbox" (Hamann, 2009: 47) from which scholars can pick what they please. The notion of governmentality then risks being employed for the explanation of very different phenomena, and without a discussion on the possible limitation of the governmentality framework (Joseph, 2010a, 2010b). The operation of structures as "conditions of possibility" are typically excluded in research on the art of government in favour of a topological approach or "empiricism of the surface" (Rose in Joseph, 2010a: 241).

Two major conclusions come from this observation. First, there is an increasing demand for the reimagining governmentality as a methodology (Joseph, 2010a). This approach may avoid the over-application of the term and a differentiation between governmentality as rhetoric and the context of its application. For studies in international affairs, such a move might help improve the sensitivity to articulations of imported or externally imposed neoliberal discourses and technologies in nonliberal parts of the globe. Second, there is a need to reground studies on the art of government in an updated version of historical materialism (Joseph, 2010a; Selby, 2007; Thörn et al., 2015), reinterpret (Rehmann, 2013) or substitut by a renewed Marxism (Resch, 1992). Some elements of Marxism are continuously found in Foucault's work (Resch, 1992) and Foucault's ideas are actively employed by Marxists. Hardt and Negri (2000) borrowed the decentralization frame, regrounded and termed anonymous power "capital", thus reinstalling the idea of class interests behind the mechanisms of oppression and discipline in an increasingly globalized world. Therborn (1982) utilized Foucault's characteristics of discourse to enhance the Althusserian view on ideology. Poulantzas (1978) effectively used the idea of decentralization in an attempt to re-establish the role of the state. Empirical studies on governmentality tend to return, consciously or not, to the importance of social interest in the production of relations of power (e.g., Findlay, Newton, 1998; Thörn et al., 2015). The recognition of social conflict and social struggle as "constitutive to the social" (Thörn et al., 2015: 93) will allow the identification of plausible explanations for the incoherence, inconsistencies, and occasional failures of governmental programs. The reintroduction of the nonessentialistic notion of interest would provide a deeper explanation of social-political processes (ibid.: 94).

Descriptive discourse analysis, frequently employed in governmentality research, was found to be reductionist (O'Malley, Weir, Shearing, 1997; Thörn et al., 2015). However, Fairclough's three-dimensional model of critical discourse analysis covers both domains 
of discourse: production and consumption (Jørgensen, Phillips, 2002). In such an analysis, a variety of articulations of power relationships, and a variety of interpretations and responses from the side of individual social actors can be reached.

The concept of governmentality is currently enjoying wide popularity in several disciplines. Dissatisfaction with its capacity to account meaningfully for the mechanisms of power and subjection is, however, growing. This paper outlines some of the issues in the application of governmentality in empirical research as being immanent to the very theoretical tradition it is grounded in. Increasingly, scholars claim to be complementing the governmentality concept by macro level theoretical constructs, or, simply, for putting governmentality "in its proper place" (Joseph, 2010a: 224). Recognizing the importance of Foucault's overall contribution to the understanding of contemporary phenomena and practices, critical scholarship acknowledges a need to recognize its conceptual and social limitations (ibid.).

\section{References}

Barnett C., Clarke N., Cloke P., Malpass A. (2008) The Elusive Subjects of Neo-liberalism. Cultural Studies, vol. 22, no 5, pp. 624-653.

Barrett M. (1991) The Politics of Truth: From Marx to Foucault, Oxford: Polity Press.

Behrent M. (2010) A Seventies Thing: On the Limits of Foucault's Neoliberalism Course of Understanding the Present. A Foucault for the 21st Century: Governmentality, Biopolitics and Discipline in the New Millennium (eds. S. Binkley, J. Capetillo), Cambridge: Cambridge Scholars, pp. 16-29.

Butler J. (1995) Conscience Doth Make Subjects of Us All. Yale French Studies, vol. 88, pp. 6-26.

Collier S. (2011) Post-Soviet Social: Neoliberalism, Social Modernity, Biopolitics, Princeton: Princeton University Press.

Collier S. (2009) Topologies of Power: Foucault's Analysis of Political Government Beyond "Governmentality". Theory, Culture, Society, vol. 26, no 6, pp. 78-108.

Dean M. (2010) Governmentality: Power and Rule in Modern Society, Los Angeles: SAGE.

Edwards R., Nicoll K. (2004) Mobilizing Workplaces: Actors, Discipline and Governmentality. Studies in Continuing Education, vol. 26, no 2, pp. 159-173.

Fejes A., Dahlstedt M. (2013) The Confessing Society: Foucault, Confession and Practices of Lifelong Learning, London: Routledge.

Foucault M. (1990) Critical Theory/ Intellectual History. Michel Foucault: Politics, Philosophy, Culture: Interviews and Other Writings, 1977-1984 (ed. L. Kritzman), New York: Routledge, pp. 17-47.

Foucault M. (1995) Discipline and Punish: The Birth of the Prison, New York: Vintage Books.

Foucault M. (1991) Governmentality. The Foucault Effect: Studies in Governmentality with Two Lectures by and Interview with Michel Foucault (eds. C. Burchell, C. Gordon, B. Miller), Chicago: University of Chicago Press, pp. 87-104. 
Foucault M. (2003) Society Must be Defended: Lectures at the College de France, 1975-76 (eds. M. Bertani et al.), New York: Picador.

Foucault M. (1997) The Essential Works of Michel Foucault, 1954-1984. Vol. 1 (ed. P. Rabinow), New York: The New Press.

Foucault M. (1980) The Confession of the Flesh. Power/Knowledge: Selected Interviews and Other Writings 1972-1977 (ed. C. Gordon), New York: Vintage Books, pp. 194-228.

Foucault M. (1981) The Order of Discourse. Untying the Text: A Post-structuralist Reader (ed. R. Young), London: Routledge \& Kegan Paul, pp. 48-78.

Giddens A. (1991) Modernity and Self-Identity: Self and Society in the Late Modern Age, Stanford: Stanford University Press.

Haferkamp H. (1985) Critique of Habermas's Theory of Communicative Action. Social Action, vol. 43, pp. 197-205.

Hamann T. (2009) Neoliberalism, Governmentality, and Ethics. Foucault Studies, no 6, pp. 37-59.

Hardt M., Negri A. (2000) Empire, Cambridge: Harvard University Press.

Hartsock N. (1989) Foucault on Power: A Theory for Women? Feminism/Postmodernism (ed. L. Nicholson), New York: Routledge, pp. 157-175.

Hessdöter F., Pubs A., Ullrich P. (2010) Prevent and Tame: Protest Under (Self)control. Rose-Luxemburg-Stiftung Manusktipte 88. Berlin: Karl Deitz Verlag. Available at: https://www.rosalux.de/fileadmin/rls_uploads/pdfs/Manuskripte/Manuskripte_88. pdf (accessed 12 June 2016).

Jørgensen M. W., Phillips L. (2002) Discourse Analysis as Theory and Method, London: SAGE.

Joseph J. (2010a) The Limits of Governmentality: Social Theory and the International. European Journal of International Relations, vol. 16, no 2, pp. 223-246.

Joseph J. (2010b) What Can Governmentality Do to IR? International Political Sociology, vol. 4, no 2, pp. 202-205.

Larsson B., Letell M., Thörn H. (eds.) (2012) Transformations of the Swedish Welfare State: From Social Engineering to Governance, Basingstoke: Palgrave Macmillan.

Lemke T. (2002) Foucault, Governmentality, and Critique. Rethinking Marxism, vol. 14, no 3, pp. 49-64.

Lemke T. (2013) Foucault, Politics, and Failure: A Critical Review of Studies of Governmentality. Foucault, Biopolitics and Governmentality (eds. J. Nilsson, S.-O. Wallenstein), Stockholm: Södertörn University, pp. 35-52.

Lilja M., Vinthagen S. (2014) Sovereign Power, Disciplinary Power and Biopower: Resisting What Power with What Resistance? Journal of Political Power, vol. 7, no 1, pp. 107126.

Mckee K. (2009) Post-Foucauldian Governmentality: What Does It Offer Critical Social Policy Analysis? Critical Social Policy, vol. 29, no 3, pp. 465-486.

Miller P., Rose N. (1990) Governing Economic Life. Economy and Society, vol. 19, no 1, pp. 1-29. 
Newton T. (1998) Theorizing Subjectivity in Organization: The Failure of Foucauldian Studies? Organization Studies, vol. 19, no 3, pp. 415-447.

O’Malley P., Weir L., Shearing C. (1997) Governmentality, Criticism, Politics. Economy and Society, vol. 26, no 4, pp. 501-517.

Palmer C. (2001) “Taming the Wild Profusion of Existing Things?” A Study of Foucault, Power, and Human/Animal Relationships. Environmental Ethics, vol. 23, pp. 339-358.

Poulantzas N. (1978) State, Power, Socialism, London: NLB.

Read J. (2009) A Genealogy of Homo-Economics: Neoliberalism and the Production of Subjectivity. Foucault Studies, vol. 6, pp. 25-36.

Rehmann J. (2013) Theories of Ideology: The Powers of Alienation and Subjection, Boston: Brill.

Resch R-P. (1992) Althusser and the Renewal of Marxist Social Theory, Berkley: University of California Press.

Ritzer G. (2008) Sociological Theories, New York: McGraw-Hill.

Rodin L. (2015) "Governmentality" in the Clinical Context: The Paradoxes of Humanization of Healthcare in Sweden. Journal of Social Policy Studies, vol. 13, no 4, pp. 643656.

Rodin L. (2016) "Developmental Talk” as Confession: The Role of Trade Union in Workplace Governance. Ephimera: Theory and Politics in Organization, vol. 16, no 2, pp. 5375.

Rutherford S. (2007) Green Governmentality: Insights and Opportunities in the Study of Nature's Rule. Progress in Human Geography, vol. 31, no 3, pp. 291-307.

Selby J. (2007) Engaging Foucault: Discourse, Liberal Governance and the Limits of Foucauldian IR. International Relationships, vol. 21, no 3, pp. 325-345.

Solomon J. (2011) Saving Population from Governmentality Studies: Translating Between Archaeology and Biopolitics. Biopolitics, Ethics and Subjectivation (eds. A. Brossat, C. Yuan-Horng, R. Ivekovic, J. C. H. Liu), Paris: L'Harmattan, pp. 190-205.

Stenson K. (2008) Beyond Kantianism: Response to Critiques. Social Work and Society, vol. 6, no 1, pp. 42-46.

Stern M., Hellberg S., Hansson S. (2015) Studying the Agency of Being Governed? An Introduction. Studying the Agency of Being Governed (eds. M. Stern, S. Hellberg, S. Hansson), New York: Routledge, pp. 1-18.

Stryker S. (2002) Symbolic Interactionism: A Social Structural Version, Caldwell: Blackburn Press.

Therborn G. (1982) The Power and the Power of Ideology, London: Verso.

Thörn H., Stern M., Hellberg S., Hansson S. (2015) How to Study Power and Collective Agency: Social Movements and the Politics of International Development Aid: Interview with Håkan Thörn. Studying the Agency of Being Governed (eds. M. Stern, S. Hellberg, S. Hansson), New York: Routledge, pp. 85-102.

Thomas O. D. (2014) Foucaultian Dispositifs as Methodology: The Case of Anonymous Exclusions by Unique Identification in India. International Political Sociology, vol. 8, no 2, pp. 164-181. 
Ullrich P. (2010) Preventionism and Absticles for Protest in Neoliberalism: Linking Governmentality Studies and Protest Research. Prevent and Tame: Protest Under (Self) control (eds. F. Hessdöter, A. Pubs, P. Ullrich), Berlin: Karl Deitz, pp. 14-23.

Wallenstein S.-O. (2013) Introduction: Foucault, Biopolitics and Governmentality. Foucault, Biopolitcs and Governmentality (eds. J. Nilsson, S.-O. Wallenstein), Stockholm: Södertörn University, pp. 7-34.

Walters W. (2012) Governmentality: Critical Encounters, London: Routledge.

\title{
Исследования правительственности: шесть «подводных камней» эпистемологии
}

\author{
Лика Родин \\ Кандидат социологических наук, преподаватель социальной психологии Университета Шёвдэ \\ Адрес: Högskolevägen, Box 408, Högskolan i Skövde, Sweden 54128 \\ E-mail: lika.rodin@his.se
}

Понятие правительственности, разработанное в работах Мишеля Фуко, активно используется в различных академических дисциплинах. На основе анализа вторичной литературы, настоящая статья выделяет и систематизирует некоторые особенности теоретического подхода Фуко, которые находят отражение в современных исследованиях правительственности. Я описываю шесть скрытых эпистемологических препятствий (эссенциализации власти, невозможность сопротивления, латентный идеализм, непоследовательное представление государственности, недостаточное обоснование микро-макросвязи и исчезающая критическая позиция) с целью стимулировать академическую дискуссию о возможных методологических прозрениях, способных преодолеть некоторые из этих трудностей. Представленные ограничения рассматриваются как имманентные общей теоретической концепции Фуко, а не как следствия отклонения от нее. Примеры исследований из сферы международных отношений и социологии используются для поддержки основных аргументов в тексте. Как показано, поиск дополнительного обоснования аналитики власти Фуко в обновленной версии исторического материализма может иметь хороший потенциал для обеспечения точности исследований правительственности и переопределения его критической направленности. Кроме того, потребуется определенный консенсус по фундаментальным понятиям исследований правительственности, что может помочь стабилизировать повестку дня исследований. Признавая общий важный вклад Фуко в понимание современных феноменов и практик, критическая наука должна учитывать его концептуальные и социальные ограничения.

Ключевые слова: Фуко, власть, сопротивление, марксизм, биополитика, идеализм, дискурсанализ 